\title{
Immunoglobulin light chain mRNA detected by in situ hybridisation in diagnostic fine needle aspiration cytology specimens
}

\author{
C J R Stewart, M A Farquharson, T Kerr, J McCorriston
}

\begin{abstract}
Aims-To demonstrate expression of immunoglobulin light chain mRNA in diagnostic fine needle aspiration (FNA) cytology specimens using an in situ hybridisation (ISH) technique; and to evaluate ISH in a series of reactive lymphoid proliferations and malignant lymphomas.

Methods-Forty diagnostic FNA specimens showing a lymphoid cell population were examined for immunoglobulin light chain mRNA expression using ISH. Aspirates were obtained from lymph node $(n=$ $34)$, salivary gland $(n=3)$, subcutaneous tissue, thyroid and breast $(n=1$ each). The cases included 20 B cell lymphomas, five cases of Hodgkin's disease and 15 reactive lymphoid proliferations. Comparison with light chain immunoreactivity was made in 36 cases and histological correlation from biopsy material was available in 24.

Results-Immunoglobulin light chain restriction was demonstrated in 14 of $20 \mathrm{~B}$ cell lymphomas using ISH and in six of 17 $B$ cell lymphomas using immunocytochemistry. A polytypic pattern of light chain expression was observed in four of five cases of Hodgkin's disease with both techniques, and in 12 of 15 and 11 of 14 reactive lymphoid proliferations using ISH and immunocytochemistry, respectively.

Conclusions-The assessment of immunoglobulin light chain expression is a useful adjunct to morphology in the diagnosis of reactive and malignant lymphoid proliferations in FNA specimens. Light chain restriction can be shown using either immunocytochemistry or ISH, but the latter is more sensitive in the diagnosis of B cell lymphoma.

(F Clin Pathol 1996;49:749-754)
\end{abstract}

Keywords: B cell lymphoma, in situ hybridisation, immunocytochemistry, fine needle aspiration.

Departments of Cytology and Pathology, Royal Infirmary, Glasgow

Correspondence to: Dr C J R Stewart,

Department of Pathology, Glasgow Royal Infirmary, Glasgow G4 0SF needle aspiration (FNA) cytology major advantages in the initial assessment of patients with lymphadenopathy. The technique is simple, inexpensive, safe, and is applicable to nosis of metastatic carcinoma or melanoma is usually straightforward in lymph node FNA specimens but the assessment of lymphoprolifboth inpatient and outpatient settings. A diag- erative lesions is generally more problematic. ${ }^{1}$ Whereas malignant lymphoma may be diagnosed on the basis of routine cytological preparations, ${ }^{23}$ in some cases it is not possible to distinguish reactive and malignant lymphoid lesions on morphology alone. ${ }^{14}$ As in histopathology, special techniques often offer a useful aid to the assessment of lymphoid proliferations and together with the cytomorphology permit an accurate diagnosis in most specimens. $^{5-7}$

Immunocytochemistry has been used in cytology specimens mainly to demonstrate $\mathrm{T}$ and $B$ cell phenotypes, aberrant expression of antigens in $T$ cell lymphomas and immunoglobulin light chain restriction in $B$ cell lymphomas. $^{8-13}$ More recently, material obtained by FNA has been used for genotypic analysis including Southern blotting and polymerase chain reaction (PCR) for demonstration of $T$ cell antigen receptor and immunoglobulin gene rearrangements. ${ }^{13-15}$ The latter are valuable techniques but are limited by loss of correlative cell morphology and the requirement for relatively high cell yields. Monoclonal B cell proliferation may also be demonstrated using in situ hybridisation (ISH) for detection of restricted immunoglobulin light chain mRNA. ${ }^{16}$ This technique offers the specificity of genotypic analysis but with preservation of cell morphology. ISH detection is also unaffected by serum immunoglobulin which produces background staining and difficulties in interpretation with some immunocytochemistry preparations. In this study we have examined light chain mRNA expression by ISH and immunocytochemistry in a series of reactive and malignant lymphoid proliferations obtained by FNA.

\section{Methods}

DIAGNOSTIC CASES

FNA specimens were obtained from 40 patients attending Glasgow Royal Infirmary with clinically palpable lesions. Two or three aspirates were performed by Cytology staff using 23 or 25 gauge needles and 10 or $20 \mathrm{ml}$ syringes. The aspirates were obtained from lymph node (34 cases), salivary gland (three cases), subcutaneous tissue, thyroid and breast (one case each). Direct smears were prepared for routine staining by the Diff-Quik, MayGrunwald-Giemsa or Papanicolaou methods and needles thereafter rinsed in normal saline. Cytospin preparations from the needle rinses were used for immunocytochemistry and ISH. 
The optimum dilution for cytospin preparations was $150-200 \times 10^{3}$ cells $/ \mathrm{ml}$.

The cytology diagnoses, which were based both on morphology and the results of special techniques, fell into three main groups:

Group $A$ : $B$ cell lymphoma $(n=20)$

Seventeen cases were considered diagnostic of $B$ cell lymphoma on the FNA specimen. In three aspirates the appearances were considered highly suggestive but not conclusive of $B$ cell lymphoma. Further subclassification of the lymphomas was not generally attempted on the basis of the FNA findings.

The diagnosis of B cell lymphoma was confirmed on subsequent excision biopsy in 14 of the 20 cases ( 11 of those considered diagnostic and all three considered suspicious on FNA). Four cases considered diagnostic of $\mathrm{B}$ cell lymphoma on FNA represented recurrent tumour after treatment and did not undergo re-biopsy subsequently. The remaining two patients were unfit for biopsy for medical reasons; however, the diagnosis of lymphoma was consistent with the clinical and radiological findings.

The biopsy findings in those 18 patients with histological correlation were of follicle centre cell lymphoma (seven cases), large $\mathbf{B}$ cell lymphoma (five cases), low grade mucosa associated lymphoid tissue (MALT) lymphoma (three cases), and lymphocytic lymphoma, myeloma and monocytoid B cell lymphoma (one case each).

Light chain expression was also examined by immunocytochemistry in 17 cases.

\section{Group B: Hodgkin's disease $(n=5)$}

Biopsy confirmation of Hodgkin's disease was obtained subsequently in four patients, showing nodular sclerosis subtype in three and nodular lymphocyte predominance (LP) subtype in one. The remaining patient who presented with a subarachnoid haemorrhage was considered medically unfit for biopsy.

Light chain expression was also examined by immunocytochemistry in all five cases.

\section{Group C: reactive lymphoid proliferation $(n=$ 15)}

Biopsy in two patients with persistent and clinically suspicious lymphadenopathy confirmed the presence of a reactive lymph node. The remaining 13 patients had no evidence of lymphoma on clinical follow up of two to 24 (average 14) months.

Light chain expression was also examined by immunocytochemistry in 14 cases.

\section{IMMUNOCYTOCHEMISTRY}

Cytospin preparations for light chain analysis were air dried and then fixed in acetone for 10 minutes. The primary antibodies were polyclonal anti- $\kappa$ and anti- $\lambda$ (Dako, High Wycombe, UK) which were incubated for one hour at a dilution of 1 in 2000. Detection was with a biotin/alkaline phosphatase labelled streptavidin method using New Fuchsin (Biogenex) as substrate.
Table 1 Light chain expression using in situ hybridisation (ISH) and immunocytochemistry (ICC)

\begin{tabular}{lrrrrr}
\hline & \multicolumn{2}{c}{ Monotypic } & & \multicolumn{2}{c}{ Polytypic } \\
\cline { 2 - 3 } \cline { 5 - 6 } Cytology diagnosis & \multicolumn{1}{c}{$I S H$} & \multicolumn{1}{c}{$I C C$} & & \multicolumn{1}{l}{ ISH } & \multicolumn{1}{c}{ ICC } \\
\hline B cell lymphoma & $14 / 17$ & $6 / 14$ & & $0 / 17$ & $0 / 14$ \\
Suspicious of BCL & $0 / 3$ & $0 / 3$ & & $0 / 3$ & $0 / 3$ \\
Hodgkin's disease & $0 / 5$ & $0 / 5$ & & $4 / 5$ & $4 / 5$ \\
Reactive lymphoid & $0 / 15$ & $0 / 14$ & & $12 / 15$ & $11 / 14$ \\
proliferations & & & & & \\
\hline
\end{tabular}

$\mathrm{BCL}=\mathrm{B}$ cell lymphoma

In addition to light chain analysis, most cases were also examined with a panel of $T$ and $B$ cell antisera for routine diagnostic purposes. These included CD3 (SAPU), CD43, CD20, CD79, and CD45 (all from Dako). Selected cases were also examined for immunoreactivity to CD15 (SAPU) and CD30 (Dako).

IN SITU HYBRIDISATION

The ISH technique was similar to that used for paraffin wax embedded tissue sections. Initial studies using aspirates from excised human tonsil had shown that optimum fixation was achieved using neutral buffered formalin, and that light chain mRNA could be detected up to seven days after sampling in both fixed and unfixed material.

Cytospin preparations were prepared on silane treated slides and fixed for 24 hours in neutral buffered formalin. The slides were washed twice in water and then digested with $20 \mu \mathrm{g} / \mathrm{ml}$ proteinase $\mathrm{K}$ (Sigma, Poole, Dorset, UK) for 30 minutes at $37^{\circ} \mathrm{C}$. Proteinase activity was stopped by washing in $0.2 \%$ glycine. Cells were post-fixed with $0.4 \%$ paraformaldehyde in phosphate buffered saline for 20 minutes at $4^{\circ} \mathrm{C}$. Prior to applying the probes, slides were washed twice in water followed by one wash in industrial alcohol, then air dried. All solutions used before hybridisation were treated with diethylpyrocarbonate.

The probes used were fluorescein isothiocyanate (FITC) labelled deoxyribonucleotide cocktails to $\kappa$ and $\lambda$ mRNA (Dako). Probes were diluted 1 in 1 with $30 \%$ hybridisation buffer $(30 \%$ formamide $\mathrm{BDH}, 10 \%$ dextran sulphate, $0.2 \%$ polyvinylpyrrolidone, $0.2 \%$ Ficoll, $5 \mathrm{mM}$ EDTA, $50 \mathrm{mM}$ Tris $\mathrm{HCl}, \mathrm{pH}$ 7.5); $20 \mu$ l of diluted probe was applied to the slides, which were then covered with a coverslip and incubated overnight at $37^{\circ} \mathrm{C}$.

Coverslips were removed in $2 \times$ SSC $(0.3 \mathrm{M}$ $\mathrm{NaCl}, 0.03 \mathrm{M}$ sodium citrate) and sequentially washed in $0.1 \%$ Triton X/TBS (0.05 M Tris $\mathrm{HCl}, \mathrm{pH} 7.6,0.15 \mathrm{M} \mathrm{NaCl}$ ) for 10 minutes and TBS for five minutes. Thereafter, slides were incubated with alkaline phosphatase conjugated rabbit anti-FITC (Dako) for 30 minutes at room temperature. Detection was achieved using NBT/BCIP (Sigma) as substrate and cells were counterstained with $1 \%$ light green.

Reactive tonsillar tissue was used as a positive control. In negative controls the ribonucleotide probes were omitted. The ISH methodology was also checked periodically by substitution of FITC conjugated random oligonucleotides (Dako), and by RNase pretreatment. 


\section{Results}

Table 1 summarises the pattern of immunoglobulin light chain expression.

GROUP A: B CELL LYMPHOMA ( $\mathrm{N}=20$ )

Of the 17 cases considered diagnostic of $B$ cell lymphoma on FNA, 14 showed light chain restriction on ISH ( $\kappa$ in 10 cases and $\lambda$ in four). In all cases, light chain expression seemed to be completely monotypic with no reaction for the alternative light chain mRNA. In most tumours strong cytoplasmic staining was observed (figs 1 and 2) but in three cases staining was more subtle, appearing as a narrow paranuclear rim in neoplastic cells (fig 3). The interpretative difficulty caused by background staining with immunocytochemistry was not observed in heavily blood stained aspirates using the ISH technique (fig 1). The

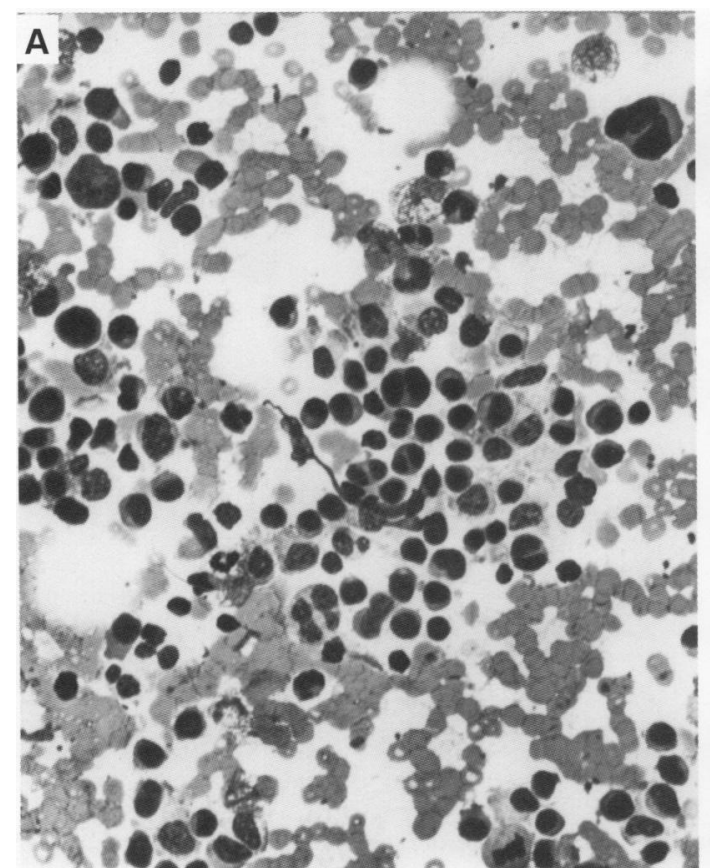

c

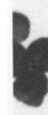

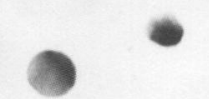
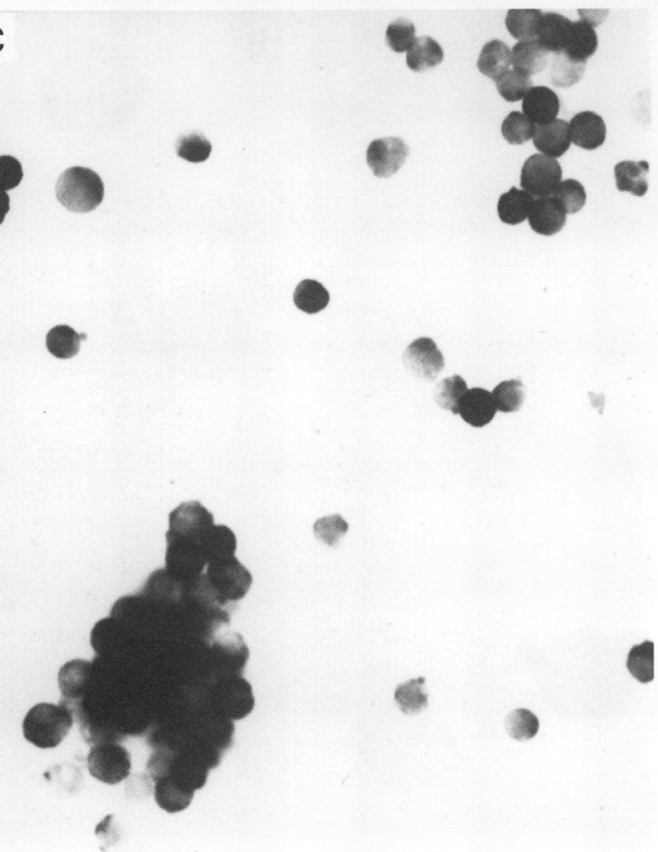

proportion of cells expressing light chain varied from about $20 \%$ to $80 \%$ of those present in the cytospin preparations. Morphologically, the cells expressing light chain mRNA included small lymphocytes, follicle centre cells, centrocyte-like cells in MALT lymphomas, large nucleolated immunoblasts and plasmacytoid cells in varying proportion in the different cases.

No staining for either $\kappa$ or $\lambda$ was seen in the three remaining cases considered diagnostic of B cell lymphoma, or in the three cases considered suspicious of lymphoma on FNA.

Light chain restriction was demonstrated in six of 14 cases diagnostic of, and in none of three cases suspicious of $B$ cell lymphoma using immunocytochemistry. In those preparations considered monotypic, light chain mRNA was expressed in about $50 \%$ to $80 \%$ of

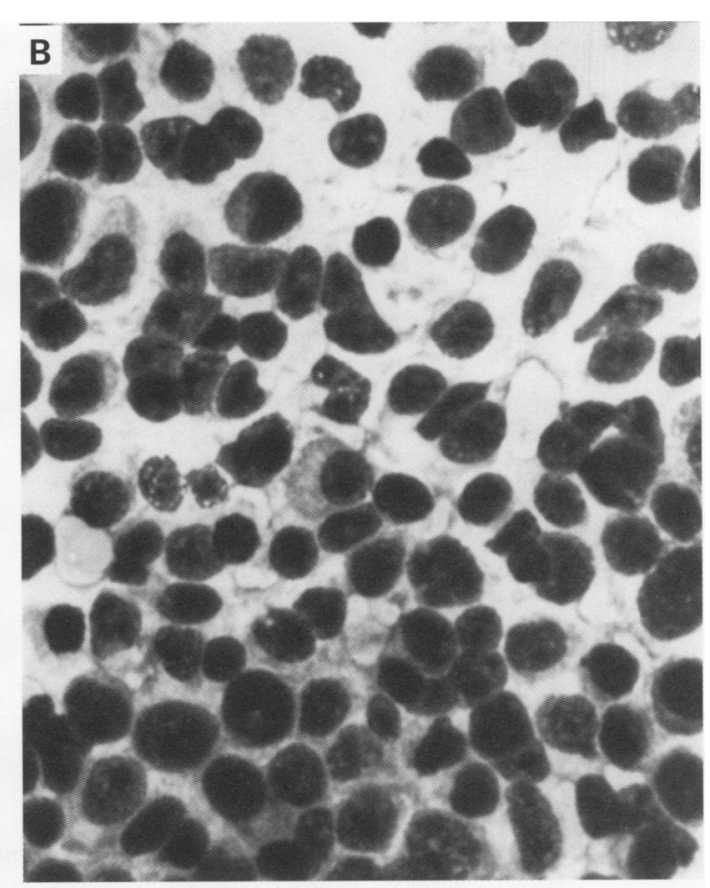

D
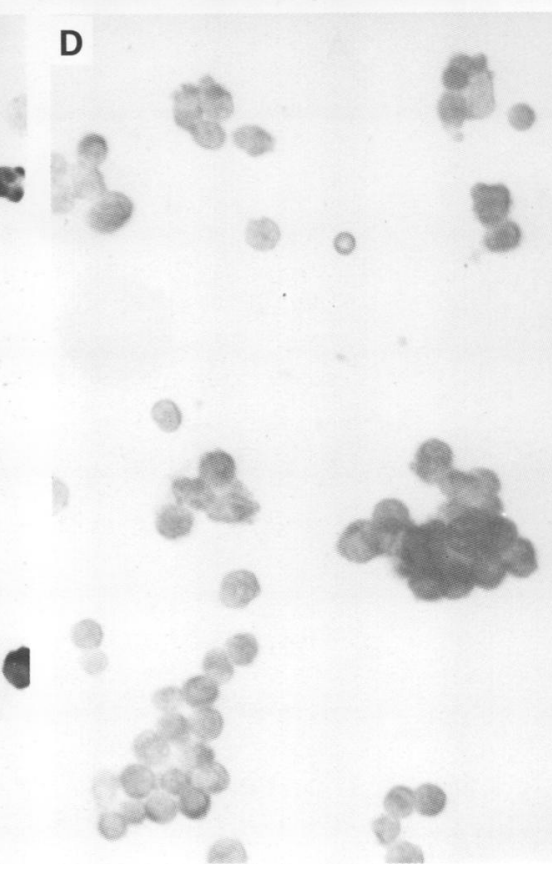

Figure 1 Large B cell lymphoma. (A) Heavily blood stained FNA specimen (May-Grunwald-Giemsa). (B) Cytological detail of atypical lymphoid cells. (C) ISH for $\kappa$ showing strong staining in most cells. (D) ISH for $\lambda$ is negative. 
cells. There was usually at least mild background immunoreactivity with the alternate light chain antiserum. In only one specimen (a follicular lymphoma) was monoclonal light chain expression demonstrated by immunocytochemistry but not ISH; a similar pattern was observed in the biopsy material from this case.

The same pattern of light chain restriction $(\kappa$ or $\lambda$ ) was shown by ISH and immunocytochemistry, and was also demonstrated in histology material in six cases.

HODGKIN'S DISEASE $(\mathrm{N}=5)$

A polytypic pattern of light chain expression was observed in four cases both with ISH and immunocytochemistry. There were few reactive cells, accounting for up to $10 \%$ of those in the cytospin preparations and mainly com-

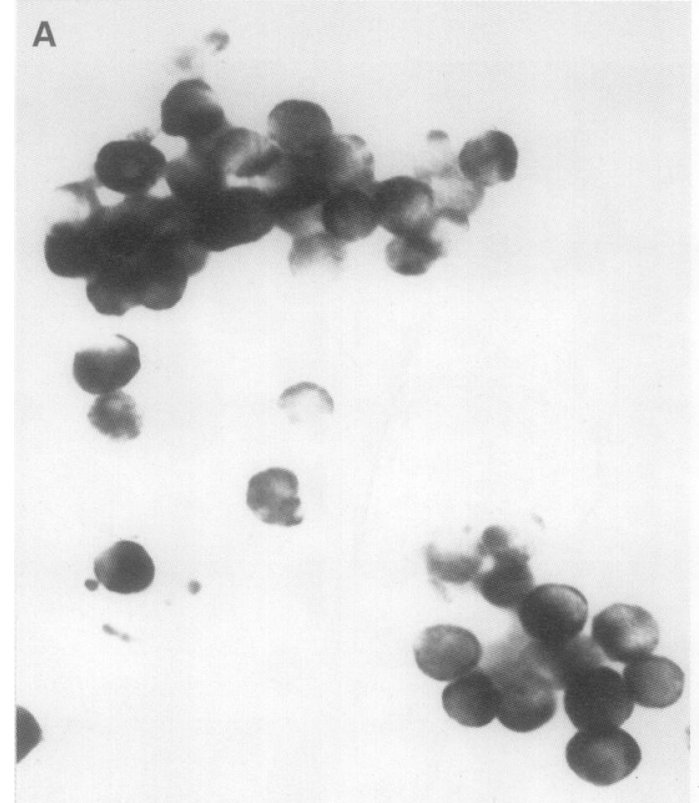

prised mature plasma cells. No staining was observed in Reed-Sternberg cells or their variants.

Light chain expression was not observed in the remaining specimen with either ISH or immunocytochemistry.

REACTIVE LYMPHOID PROLIFERATION $(\mathrm{N}=15)$

A polytypic staining pattern was observed in 12 of 15 cases using ISH and in 11 of 14 cases with immunocytochemistry. As with the specimens from Hodgkin's disease, relatively few cells (less than 20\%) expressed light chain mRNA and these mainly comprised mature plasma cells with occasional larger cells of probable follicle centre cell origin (fig 4).

No staining was observed in the remaining cases using either technique.

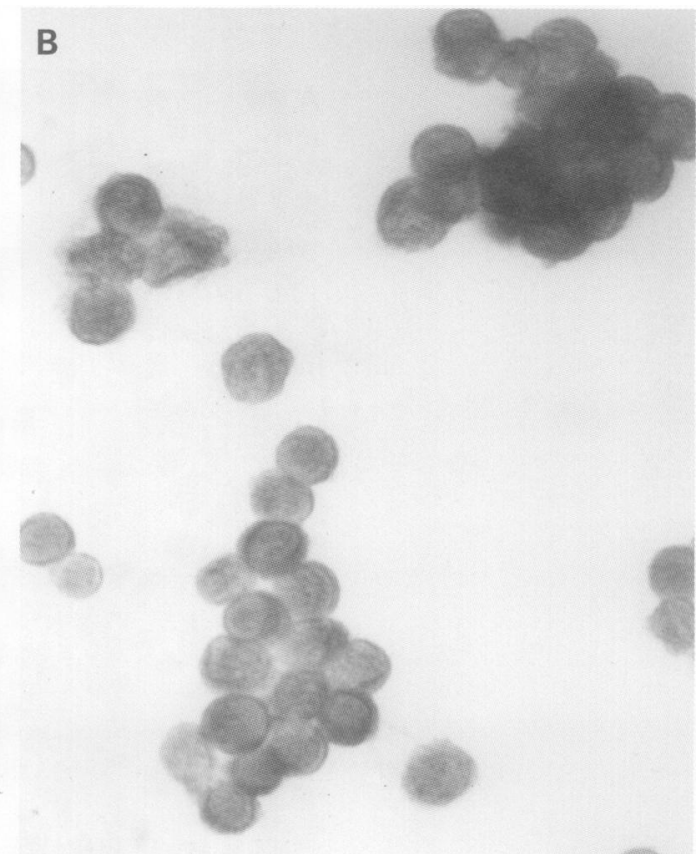

Figure 2 Follicular lymphoma. (A) ISH for $\mathrm{\kappa}$ showing strong staining in most cells. (B) ISH for $\lambda$ is negative.

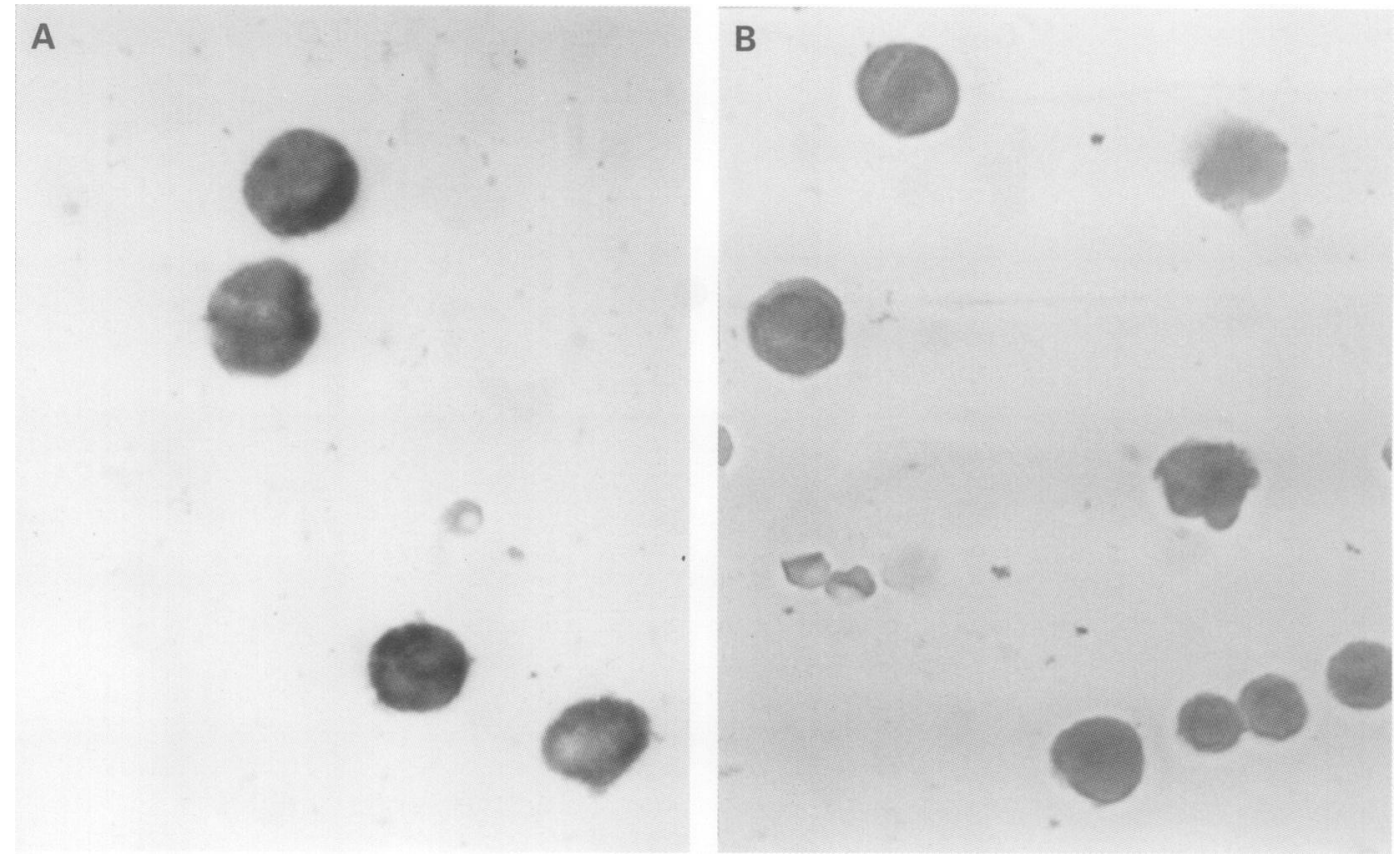

Figure 3 MALT lymphoma. (A) Staining of paranuclear cytoplasmic margin on ISH for $\lambda$ in centrocyte-like cells. (B) ISH for $\mathrm{K}$ is negative. 


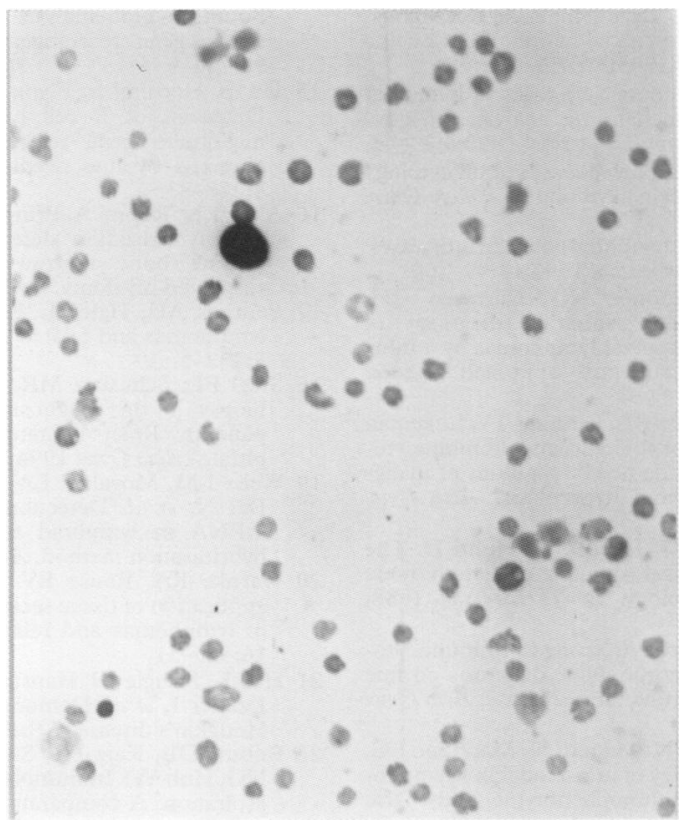

Figure 4 Reactive lymph node. A plasma cell strongly expresses $\kappa$ light chain $\mathrm{mRNA}$. Other cells are unstained. $A$ similar pattern was observed on ISH for $\lambda$

\section{Discussion}

The differentiation of reactive lymphadenopathy from lymphoma presents the most common diagnostic dilemma in the assessment of lymphoid FNA specimens. In cytology preparations the architectural pattern of lymph node or other tissue is lost and suspicion of lymphoma is usually based either on the relatively monomorphic nature of the lymphoid cell population or on the presence of obvious cytomorphological abnormalities. ${ }^{17}$ However, some B cell lymphomas, particularly follicle centre cell type, initially appear polymorphous and most aspirates also include an admixed population of reactive cells such as $\mathrm{T}$ lymphocytes. In addition, overtly abnormal lymphoid cells are not seen in most low grade lymphomas. The difficulty is illustrated by a recent large series of lymph node FNA in which low grade non-Hodgkin's lymphomas were the commonest cause of false negative diagnostic error. ${ }^{18}$ Thus, ancillary techniques which provide phenotypic and genotypic analysis are of great value in the assessment of lymphoid proliferations in cytology material. $^{57}$

The presence of immunoglobulin light chain restriction has been used to indicate a monoclonal B cell proliferation as this generally implies a neoplastic rather than reactive lymphoid process. Immunocytochemistry is the established method of demonstrating light chain expression but may be of limited value in some cases as a result of partial nodal involvement by lymphoma, predominance of reactive $T$ cells in some tumours ( $T$ cell rich $B$ cell lymphoma), non-secretory types of $B$ cell lymphoma or background polytypic immunoglobulin staining. ${ }^{919}$ The latter creates the most common interpretative problem in our experience, particularly in bloodstained FNA specimens, and similar difficulty may be encountered in tissue sections of biopsy material. ${ }^{20}$ In addition, cytoplasmic immunoreactiv- ity may result from diffusion or active uptake of immunoglobulin and as such is non-specific. ${ }^{21}$ In this series light chain restriction was shown in only six $(35 \%)$ of 17 cases of B cell lymphoma by immunocytochemistry. Similarly, Pilotti et al found immunochemistry of limited value in differentiating lymphoid hyperplasia and lymphoma. However, other cytological studies have described light chain restriction in over $90 \%$ of B cell lymphomas using immunocytochemical methods. ${ }^{910} \mathrm{Re}-$ cently, Robins et al demonstrated monoclonality in 57 and 58 of $63 \mathrm{~B}$ cell lymphomas using immunocytochemistry in cytospin preparations and flow cytometry, respectively. ${ }^{22}$

The ISH technique, by relying on detection of cellular mRNA, offers increased specificity compared with immunocytochemistry. In addition, the complete absence of background immunoglobulin staining permits detection of a monotypic B cell population even when the tumour clone comprises a minority of cells present in cytospin preparations. ISH has been used to demonstrate light chain mRNA expression in histological sections of bone marrow $^{16}$, salivary gland ${ }^{23}$ and lymphoid tissue, ${ }^{19}{ }^{21}$ but to our knowledge has not been described previously in cytology material. In this series ISH demonstrated light chain restriction in 14 of $20 \mathrm{~B}$ cell lymphomas diagnosed on FNA cytology. The sensitivity of the technique was therefore approximately twice that of immunochemistry, and greater than that described with ISH in tissue sections of $B$ cell lymphoma by Weiss et al. ${ }^{19}$ In addition, the presence of both $\kappa$ and $\lambda$ light chain in aspirates was of value in supporting a diagnosis of reactive lymphoid proliferation in 12 of 15 cases. However, a polytypic pattern was also seen in four of five cases of Hodgkin's disease and it is important to appreciate that co-expression of immunoglobulin light chain in FNA material does not exclude a diagnosis of lymphoma. ${ }^{8}{ }^{1024}$ Interestingly, the tumour cells in the single case of nodular LP Hodgkin's disease in this study did not express immunoglobulin light chain; this Hodgkin's subtype is now generally regarded as a lymphoma of B cell origin, and light chain restriction was demonstrated by ISH in approximately half the biopsy cases reported by Hell et al. ${ }^{21}$

In summary, light chain expression may be demonstrated on lymphoid cells using an ISH technique on cytospin preparations. The use of ISH contributed to a $100 \%$ specificity for the diagnoses of B cell lymphoma, Hodgkin's disease and reactive lymphoid proliferations in a series of 40 FNA specimens. ISH was more sensitive than immunocytochemistry $(70 \% v$ $35 \%)$ in detecting light chain restriction in the cases of B cell lymphoma.

1 Orell SR, Sterrett GF, Walters MN-I, Whitaker D (eds) Manual and atlas of fine needle aspiration cytology. Edinburgh: Churchill Livingstone, 1992:63-94

2 Das DK, Gupta SK, Datta BN, Sharma SC. FNA cytodiagnosis of non-Hodgkin's lymphoma and its subtyping under Working Formulation of 175 cases. Diagn Cytopathol 1991;7:487-98.

3 Carter TR, Feldman PS, Innes DJ, Frierson HF, Frigy AF The role of fine needle aspiration cytology in the diagnosis of lymphoma. Acta Cytol 1988;32:848-61. 
4 Pilotti S, Di Palma S, Alasio L, Bartoli C, Rilke F. Diagnostic assessment of enlarged superficial lymph nodes by fine needle aspiration. Acta Cytol 1993;37:853-66.

5 Sneige N. Diagnosis of lymphoma and reactive lymphoid hyperplasia by immunocytochemical analysis of fineneedle aspiration biopsy. Diagn Cytopathol 1990;6:39-43.

6 Skoog L, Tani E. The role of fine-needle aspiration cytology in the diagnosis of non-Hodgkin's lymphoma. Diagn Oncol 1991;1:12-18.

7 Katz RL, Caraway NP. FNA lymphoproliferative diseases: myths and legends. Diagn Cytopathol 1995;12:99-100.

8 Cafferty LL, Katz RL, Ordonez NG, Carrasco CH, Cabanillas FR. Fine needle aspiration diagnosis of intraabdominal and retroperitoneal lymphomas by a morintraabdominal and retroperitoneal lymphomas by a morphologic and

9 Sneige N, Dekmezian RH, Katz RL, Fanning TV, Lukeman $\mathrm{JL}$, Ordonez NG, et al. Morphologic and immunocytochemical evaluation of 220 fine needle aspirates of malignant lymphoma and lymphoid hyperplasia. Acta Cyto 1990;34:311-22.

10 Oertel J, Oertel B, Kastner M, Lobeck H, Huhn D. The value of immunocytochemical staining of lymph node
aspirates in diagnostic cytology. $\mathrm{Br} \mathscr{f}$ Haematol 1988; 70:307-16.

11 Tani EM, Christensson B, Porwit A, Skoog L. Immunocytochemical analysis and cytomorphologic diagnosis on fin needle aspirates of lymphoproliferative disease. Acta Cyto 1988;32:209-15.

12 Daskalopoulou D, Harhalakis N, Maouni N, Markidou SG. Fine needle aspiration cytology of non-Hodgkin's lymphomas. A morphologic and immunophenotypic study. Acta mas. A morphologic

13 Cartagena N, Katz RL, Hirsch-Ginsberg C, Childs CC, Ordonez N, Cabanillas F. Accuracy of diagnosis of malignant lymphoma by combining fine-needle aspiration cytomorphology with immunocytochemistry and in seclected cases Southern blotting of aspirated cells. Diagn Cytopathol 1992;8:456-64.

14 Williams ME, Frierson HF, Tabbarah S, Ennis PS. Fine-needle aspiration of non-Hodgkin's lymphoma:
Southern blot analysis for antigen receptor, bcl-2, and c-myc gene rearrangements. Am ff Clin Pathol 1990 93:754-9.

$15 \mathrm{Hu}$ E, Horning S, Flynn S, Brown S, Warnke R, Sklar J. Diagnosis of $\mathbf{B}$ cell lymphoma by analysis of immunoglobulin gene rearrangements in biopsy specimens obtained by fine needle aspiration. F Clin Oncol 1986; 4:278-83.

16 Akhtar N, Ruprai A, Pringle JH, Lauder I, Durrant STS. In situ hybridization detection of light chain mRNA in routine bone marrow trephines from patients with suspected myeloma. Br f Haematol 1989;73:296-301.

17 Pontifex AH, Haley L. Fine-needle aspiration cytology in lymphomas and related disorders. Diagn Cytopathol 1989 5:432-5.

18 Steel BL, Schwartz MR, Ramzy I. Fine needle aspiration biopsy in the diagnosis of lymphadenopathy in 1,103 patients. Role, limitations and analysis of diagnostic pitfalls. Acta Cytol 1994;38:76-81.

19 Weiss LM, Movahed LA, Chen YY, Shin SS, Stroup RM Bui $\mathrm{N}$, et al. Detection of immunoglobulin light-chain Bui N, et al. Detection of immunoglobulin light-chain mRNA in lymphoid tissues using a practical in

20 Warnke RA, Rouse RV. Limitations encountered in the application of tissue section immunodiagnosis to the stud of lymphomas and related disorders. Hum Pathol 1985; 16:326-31.

21 Hell K, Pringle JH, Hansmann M-L, Lorenzen J, Colloby P, Lauder I, et al. Demonstration of light chain mRNA in Hodgkin's disease. $₹$ Pathol 1993;171:137-43.

22 Robins DB, Katz RI Swan F J Atkinson EN, Ordonez NG, Huh YO. Immunotyping of lymphoma by fine-needle NG, Huh YO. Immunotyping of lymphoma by fine-needle aspiration. A comparative study of cytospin preparation
and flow cytometry. Am $\mathcal{F}$ Clin Pathol 1994;101:569-76.

23 Speight PM, Jordan R, Colloby P, Nandha H, Pringle JH. Early detection of lymphomas in Sjogren's syndrome by in situ hybridisation for and light chain mRNA in labial salivary glands. Eur $\mathcal{F}$ Cancer Oral Oncol 1994;30B:244-7.

24 Sneige N, Dekmezian R, El-Naggar A, Manning J. Cytomorphologic, immunocytochemical and nucleic acid Clow cyorphologic, im 50 lymph nodes by fine-needle aspiration. Cancer 1991;67:1003-7. 